\title{
Was Political Realism the Theoretical Basis for the National Security Doctrine? Reflections on the Matter
}

\author{
Pedro Rivas Nieto ${ }^{1} \&$ Roberto Gelado Marcos ${ }^{1}$ \\ ${ }^{1}$ Pontifical University of Salamanca, Spain \\ Correspondence: Pedro Rivas Nieto, Pontifical University of Salamanca, C/Henry Collet 90-98, (37.007) \\ Salamanca, Spain. Tel: 92-335-5560/ 61-649-6424/ 92-328-2750. E-mail: privasni@upsa.es
}

Received: January 10, 2012

Accepted: January 29, $2012 \quad$ Online Published: October 18, 2012

doi:10.5539/par.v1n1p24

URL: http://dx.doi.org/10.5539/par.v1n1p24

\begin{abstract}
This paper will investigate to what extent the following idea, which became very popular during the last third of the twentieth century in Latin America, is true: that political realism was the ideological foundation of the National Security Doctrine. In other words, did the theorists of the National Security Doctrine inspire their postulates on key authors of this international relations paradigm? If so, did they use political realism to build their own political culture and their authoritarian-bureaucratic regimes, with a sharp military style? Bearing in mind that the specificities of this kind of regimes are already well-known, little attention will be paid to it in this text. As a matter of fact, this paper will focus on how realism operates ideologically, in order to check the applicability of the aforementioned relation.
\end{abstract}

Keywords: political realism, national security, authoritarianism, democracy

\section{Introduction}

The origins of the concept of "National Security" date back to the moment in which the United States entered the imperial age, before Second World War. Spykman developed the concept, influenced by Harfold J. Mackinder Geopolitics and by Alfred T. Mahan (Note1). The euphoria of the victory helped to start an imperial process and the increasing power of the States reduced the classical scepticism inherited from leaders of the nineteenth and early twentieth centuries. Besides, the Cold War made the expansion of the American influence in the world become more urgent. The new attitude of Americans towards world affairs after the Second World War, the permanent concern about crises, the thrills of leading the world and the imperatives of duty, mistaken with the chances created by increased power speeded up the process started in 1945 and made "national security" become a prioritized value.

The United States took up the space left by the fall of the European empires whilst the Soviet Union started to be seen by American interpreters as an irreconcilable rival. As a matter of fact, the mentality of the era needed to face those threatening to destroy all the things that had been so difficult to build. Historically speaking, it was nothing new that a whole population had to face a new enemy whose vision was radically opposed to theirs. But Communism was a social system that had been able to build a blind faith in itself, and whose application had no constraints. That made it become very dangerous. And that was precisely why it had to be fought fiercely.

Not for naught, as pointed out by Burnham, who was aware of how necessary was that the United States played a leading role in the world, did the Third World War have began in April 1944, when a group of Greek seamen under British command joined some Greek soldiers who were entrenched in Alexandria and started a mutiny. They were immediately subdued and imprisoned for a short time in a concentration camp. The implications of the revolt were not that unimportant, because the insurgents followed orders by the ELAS (the People's Liberation Army), the armed force of the EAM (the National Liberation Front), which was lead by the Greek Communist Party, which at the same time was ruled by the CPSU (the Communist Party of the Soviet Union). The rising of April 1944 and the subsequent Greek civil war in the manichaeist conception of those who interpreted those affairs as a struggle between good and evil were the precedent of the clash between international Communism and the democratic order (Burnham, 1947:1). Thus the winner of the Second World War would have to lead international affairs from then on. The imperial role was assumed in a new context: the Cold War. And that started the preparation for a new system because, in fact and many political leaders agreed with this, it was the survival of the Western civilization what was at stake. 


\section{The Mystics of Post-War Times and the Concept of National Security}

It must be noted here that empire has been the most efficient form of government ever in human history (Kissinger, 1995:12). In like manner, it must be pointed out that empire does not intend to find a privileged place within the international order. Rather it aspires to become the international order itself. A world empire is a type of system in which the whole globe is dominated through coercion, and in which a sole group of people hold most of the power. For Americans, the word empire evokes and so it did in those years as well ideas of tyranny and despotism. However, empires are also compatible with democracy and do not need to intervene in all the activities within a society. This does not happen in other regimes, whose essence is more invasive. Burnham himself stated that empire was the only feasible option in the post-Second World War era and, should any of both contenders win, its ideas would constitute the basis for the new empire that would emerge as a result of such struggle (Burnham, 1947).

Be it as it may, the National Security Doctrine took form, partly, in the United States. Though its name, it was not exactly a doctrine. Rather it was a whole culture whose definition was vague and complex. In the States, it represented a highly desired value, so it needed no explanation, nor justification. It was more important than any reflection that could be made about it, and it was presumed that everybody knew what it meant. But they did not, and that made academic research on the topic more difficult -it still does, actually- because those studies had to deal with an imprecisely defined concept.

National Security was, above all, a mystic symbol. Schlesinger said that "the very term 'national security' was an incantation in the Nixon White House (...) The very words served to block critical analysis. It seemed at least presumptuous if not unpatriotic to inquire into just what the significance of national security was" (Schlesinger, 2004: 457). Notwithstanding, though the sense of the words was never clarified, National Security became such an important issue that it became the subject of a new discipline: the National Security affairs. By the mid 1950s, a fruitful and prolific academic world was born around the concept of National Security, and it actually tried to deepen the knowledge of the new subject. The definition of the doctrine was still vague after that, but facts proved that in practical terms it was very concrete.

The mystics of National Security revealed itself as an infallible criterion to tell right from wrong. If Batista, Diem, or Chiang Kai Chek proved to be anticommunist enough, National Security demanded absolute support for them. National Security became the value that obliterated all the others, the one "to which other values could be properly sacrificed in times of crisis" (Kissinger, 1995:130). So, from the end of the Second World War to the Nixon Presidency, National Security became an urgent goal. Even afterwards it seemed to gain strength in other ways. The old American belief that the world should be guided by the rule of the law progressively faded away, partly because of the rising importance granted to the CIA as a tool for foreign affairs. Its greatest contribution was to focus, while in peace, on covert activities to change politics and regimes in other countries. Instead of being satisfied with finding out what was happening, the CIA went far beyond than other secret services and tried to make things happen (Schlesinger, 1999:83). And that became a reality without essentially contradicting the deep-rooted American democratic tradition or the nation's inner paradoxes. As a matter of fact, those countries violating human rights, such as Chile, Argentina, Paraguay or Cuba to name but a few in South America-, and as far as strategic considerations did not state otherwise, were denied American aid or "permitted it only under severe restrictions" (Schlesinger, 1999:96). The Bureau of Human Rights, which was created within the Department of State by the Carter Administration, proved human rights had become part of American foreign affairs policies. What is more, American embassies abroad also became a kind of human rights watchdogs since then. These incongruities reaffirmed the words of Henry James, who poetically said that being an American is a complex fate (James, 1920:13).

\section{Ideological Foundations of the National Security Doctrine and their Weak Links to Political Realism}

Once all this has been said, one might wonder about the ideological foundations that gave cause for the concept of National Security. To begin with, it must be highlighted that the United States fought with all their might in two World Wars that did not threaten their territory in a direct manner. At the same time, the States entered both wars without a clear idea about the goals they wanted to achieve: in principle, they just wanted a victory in order to enjoy a lasting period of peace afterwards. The only way to justify war was to declare that the nation was not being defended from a direct attack, but from a far-off threat. This same idea was valid after the war, because even though the USSR did not threat the US territory, it actually did threat its national security. As a result of this, the concept of security was glorified. Numerous national academics considered that the USSR foreign policy had to be interpreted from the notion of universal messianism, which was inherent to the Marxist doctrine. In other words, the Soviet foreign policy could only be understood as a result of two of the most desired aspirations of the 
USSR: the global revolution and the surrender of the world to Stalinism. Communism believed itself to be the master of historic destiny (Niehbur, 2008), so the main goal of the Soviet policy was to establish its regime all over the world, with no exceptions. From the times of the Communist Manifesto, Marx said to his followers that they had a world to win (Marx \& Engels, 1998). Part III of the Programme of the Comintern was precisely entitled: "The ultimate aim of the Communist International World Communism". Besides, Stalin stated that the supreme historic problem of the Russian Revolution was the need to promote world revolution. Paraphrasing Lenin, Stalin admitted that "the existence of the Soviet Republic side by side with imperialist states for a long time is unthinkable. One or the other must triumph in the end. And before that end comes, a series of frightful collisions between the Soviet Republic and the bourgeois states will be inevitable" (Lenin, 1919).

In other words, every confrontation with the Capitalist world would be unavoidable and always defensive. Either Communism conquered the world, or it would be destroyed. If open war had not taken place yet, that was only because it has been decided to move war towards a different environment: that of the Cold War. And, acknowledging that the latter did not represent a true danger for the US territorial integrity, it actually did create a permanent threat against national security.

It is important to point out that, in this convulse world, the ideas of the political realists reinforced the contents of the National Security Doctrine, though very likely they were misinterpreted by those who developed it. The school of Realism was a reaction against political Idealism. Realists criticized the former for the lack of applicability of his postulates in real situations, and therefore he was accused of clearing the path either for ingenuity or ignorance for dangerous swashbucklers like Hitler. If Bacon had said that the empire of man over nature would replace the empire of man over man, that reasoning was developed in the nineteenth century by Herbert Spencer, as a philosophical concept, and by Woodrow Wilson, as a tangible reality in Politics. In 1917, Wilson said to the Congress of the United States that that was the start of a new period in which governments and nations should try, as a result of the mistakes they have made, to adopt the same behavior shown by citizens in civilized countries. Kant himself believed commercial spirit could not coexist with war, and added that the use of the force was detrimental to the ability to reason (Kant, 2005:76), so the liberalism emanated from the Treaty of Versailles could not leave those ideas aside. Wilson showed the essence of what foreign policy was for Liberals in his speech to the Congress of January $8^{\text {th }}, 1918$, when he defended "the war to end war".

Realism was different. It did not want to be as incongruent as the beautiful but ineffective laissez-faire, which Mcllwain defined as "little more than maintenance of the status quo, and that meant the retention of traditional abuses as well as traditional rights" (McIlwain, 2005:141). Realism defended a harsh view of the interstate reality (Note 2). It aimed not to limit its activity to the academic field or the treaties that filled shelves in libraries. On the contrary, it wanted to influence the foreign policy of the States, as well as to guide them. What is more, it aspired to develop a general theory of international relations that could be applied all over the world, in order to build a fully rational foreign policy worldwide. Therefore, the ultimate goal was to improve the legacy realists had inherited by that time. Its starting point was the uttermost discarnate anthropological pessimism. Realism assumed that conflict was natural between States and so it was among men, and insisted that the State had to be the most relevant actor within the international relations system. If international politics were a struggle for power, power was the key to achieve the national interest, which at the same time should rule the acts of the States. Political action could not be restricted by the moral principles that ruled individual lives. In other words, a "double moral" was needed. In order to achieve that, the only ruling mechanism that was feasible was the classical system of balance of power (Note 3), which became an essential factor in a society of sovereign States (Morgenthau, 1977).

This was, roughly speaking, what the realist doctrine was about. This does not necessarily follow that the builders of this doctrine lacked of respect for their kind or that a sort of abject moral made them become unscrupulous men as it is often said. On the contrary, their own vital experience had made them become aware of the weakness of the democratic order, to the point that they committed to the task of improving the world they have inherited. When they were accused of "selfishness" or "immorality" for calling for double moral standards and national egotism, a key idea was being left aside: they did not mean those concepts had a sacred and unaltered value. Rather they thought idealism hid a will of power or brought peoples to disaster because it was not compatible with the essence of true politics between States (Note 4). Realism let everyone become aware of the interests others may have, and it did so more than idealism and its obsession for abstract principles did.

The laboratory where they obtained their ideas from was History itself. And perhaps, like Emerson, they did not find it necessary to analyze History in a very complex way, because they believed that current issues were provoked by quite simple causes (Emerson, 1910-14). Several realists suffered Nazi atrocities; they had to escape from National Socialism and to live in the outrageous times such evil regime caused. In this respect, 
Morgenthau wisely and pessimistically wrote that "what is interesting theoretically is how easily a democratic order can transform itself into a fascist order into what you might call the exact opposite" (Morgenthau, 2004).

Realists like Morgenthau considered to be the founder of realism in the modern theory of international relations, Kennan, Niebuhr or Osgood tried to prove that the relations between States were not ruled by Christian moral, but by pure and simple power. The philosophical and historical roots of realism were not new. Its foundations were the state of nature of Hobbes, the reason of State of Machiavelli and the Metternich's diplomacy of balance of power. All of them were systematized through the work of Morgenthau and applied to the world of the Cold War. Realists took the postulates of nineteenth century pangermanists about the inherent egotism of all national policies. That was why they believed that if the whole relationship system between States was determined only by the use of force, the ultimate goal of every national policy should be to defend the national interest. Nevertheless, the concept of national interest was pretty obscure. Though it aspired to be an objective category of analysis, its double use as an instrument of analysis and as a political tool (Rosenau, 1972) just weakened it. The vagueness of the concept may indeed hide some political excesses.

Morgenthau said that survival was the first constitutive element of the national interest. Therefore, as far as the foreign policy became a struggle for survival, the States could use all means to achieve their goals (Morgenthau, 1952a:3-13). Without any doubt, Thucydides, Machiavelli, Richelieu, Hamilton or Disraeli would have understood international politics in a similar way as a never ending struggle between survival and power, despite moral condemnations by the Church or by those writers opposed to Machiavellism. After all, the selfishness of nations is proverbial, and even George Washington said nations should not be expected to go beyond their own interests.

Niebuhr, theologian and protestant, insisted that the nations were more united by the use of the force and by emotional bonds than by the reason. "Since there can be no ethical action without self-criticism, and no self-criticism without the rational capacity of self-transcendence, it is natural that national attitudes can hardly approximate the ethical" (Niebuhr, 2002). What is more, he believed that the nations were not aware of their own self until they did not see themselves in a war situation against other nations. That was the reason why he criticized "sanctimonious hypocrisy" (Niebuhr, 2002) by both those leaders who evoke moral rules to justify their acts, and those idealists who think they can count on material and moral resources that have not existed in all human History, nor in mankind itself. After all, he thought that "perhaps the best that can be expected of nations is that they should justify their hypocrisies by a slight measure of real international achievement, and learn how to do justice to wider interests than their own, while they pursue their own" (Niebuhr, 2002).

It must be remembered that the father of realists, as Kennan called him, thought that human beings were marked by original sin, and that they can obviously act in an evil way, for they were not born innocent. Life, he said, was a struggle for power, and war was the result of that wickedness. Democracy itself was just possible if it took into account the complexity of human nature, it was feasible because men were capable to do justice, and it was necessary because of men's natural inclination to injustice (Niebuhr, 1960). Niebuhr thought that the collective beings that build the States were worst than individuals and that it was just by force that all States were either born or kept alive. Philosophers of the social contract, who believed in peace through law enforcement, were obsessed to omit that the corruption of men through sin found its highest expression in the violent course of History. What is more, Niebuhr insisted that realism did not have to be cynical, because the antidote against pretentious idealism which alleges to know more about men than what it is to know is focus both on oneself and on the other, as a result of the awareness of the limits of one's knowledge and power (Davis \& Good, 1960). Niebuhr was a philosopher of foreign policy and there is no big difference in that field between his postulates and those of Osgood, another realist who believes that every war declared aiming to achieve transcendent goals was simply immoral. As far as men kept on being what they were, wars will never cease, and the attempts to eradicate them on behalf of high moral goals were dangerous because reality never surrender to dreams or sublime ideals. Abstract ideals could intoxicate international relations. Nations should renounce war as a political tool unless they were to defend national politics (Osgood, 1957). Therefore, national egotism was the most sensible and moral attitude.

If we further research the ideological foundations of political realism in order to test whether it inspired the National Security Doctrine or not, there is another key figure to be studied: George Kennan. Kennan combined his political activity with his job as a university lecturer and, though he did not bring anything essentially new to the theory of international relations, he was the creator of the containment doctrine. He applied it actively when working first as a diplomat in Moscow and afterwards as a secretary of State. As a matter of fact, in his popular paper "The Sources of Soviet Conduct", published in 1947 in Foreign Affairs (Note 5), he stated that US actions towards the USSR must be ruled by a philosophy of patient, firm and long-term contention of the Soviet 
expansive inclinations. Moreover, he foresaw progressive weakening of the USSR and predicted that their opponent was not so strong as it might be believed, so it was not unlikely that it may ultimately fall, though its apparent indestructibility. That is why he said that

"Russia, as opposed to the Western world in general, is still by far the weaker party; that Soviet policy is highly flexible, and that Soviet society may well contain deficiencies which will eventually weaken its own total potential. (...) It is entirely possible for the United States to influence by its actions the internal developments, both within Russia and throughout the international Communist movement" (Kennan, 1947).

However, those in charge of the US foreign policy, who publicly spoke about a uniform Communist, threat in order to get internal consensus for internationalism, privately acknowledged that world politics could not be defined in such a simplistic manner (Cf. Hall \& Ikenberry, 1989). Kennan recommended a flexible foreign policy that took into account that Communism would rather crack because of the nations; therefore the new scenario would not be a bipolar clash but the classical balance of power (Gaddis, 1982). In other words, he proposed to turn back to traditional political prudence, far from the inflexibility of simplistic interpretations and also from the inflexibility of the Law. He bluntly summarized his postulates as follows: "We must be gardeners and not mechanics in our approach to world affairs" (Kennan, 1954) (Note 6).

In like manner, it is impossible to forget the theoretical and practical influence of Henry Kissinger, International Relations professor at Harvard and Secretary of State with Richard Nixon, both for realism and for the National Security Doctrine. He put into practice part of his theory and defended always the need for traditional diplomacy and balance of power in order to maintain world stability.

"Its goal was not peace so much as stability and moderation. By definition, a balance-of-power arrangement cannot satisfy every member of the international system; it works best when it keeps dissatisfaction below the level at which the aggrieved party will seek to overthrow the international order" (Kissinger, 1995).

The aim of foreign policy, he said, is not peace in itself, which was an old obsession of idealists, because when that became the main principle of the policies of all States, international order was at the mercy of the most ruthless leader.

Kissinger feared revolutionary powers because they questioned the validity of the international system itself. That is why he thought how to found a stable order after a revolutionary process (Note 7) and, applying that idea to his times, he wondered how he could integrate the USSR in the post-Yalta world order. Stable systems were the consequence of a legitimacy agreed by all powers and, even though that did not avoid wars, in case of an armed conflict, it did not question the legitimacy of the whole system either. Diplomacy only works well in that environment. However, a system can be called revolutionary if one of the powers within it believes that either the international order itself or the ways of legitimizing it are oppressive. The relationships between that power and the rest of the world would be revolutionary, and what is typical of such a power is that is always ready to take their foreign policy principles to their ultimate consequences. In case of war, it is not the power or the survival of a nation what is at stake, but the system itself, and in such an environment, classical diplomacy cannot work properly.

"Whether an international order is relatively stable, like the one that emerged from the Congress of Vienna or highly volatile, like those that emerged from the Peace of Westphalia and the Treaty of Versailles, depends on the degree to which they reconcile what makes the constituent societies feel secure with what they consider just" (Kissinger, 1995).

The lessons of History were not useful for the bipolar world of the post-war era, and Kissinger wanted the United States to play a decisive role to create a stable system based on nuclear dissuasion with a strategic model of limited war. Though, in a famous interview with the Italian journalist Oriana Fallaci, he said of himself, surprisingly, that he was a follower of Spinoza and Kant (Fallaci, 1976), but he has been always considered the true heir of Machiavelli and, most likely, he has been a follower of Metternich. It was necessary to integrate the USSR within the system, he said, and also to hold them back, no matter how. His coldness as a Secretary of State and his support for the most belligerent anticommunism worldwide made him become the main instigator of the regimes inspired in the National Security Doctrine, such as Brazil or Chile, whose leaders saw Kissinger as an inspiration and a helping hand.

Realist and also neorealist (Note 8) authors in the United States thought they were introducing a more restrained type of war. As stated before, they mistrusted those wars declared on behalf of the highest ideals. They did believe too that if wars were declared on behalf of the national interest, they would be more restrained, because States would bear in mind the national interest of other States in order to get an idea of what their reactions 
would be -which, in like manner, would force them to be more cautious-. Besides, realists, like Beard or Morgenthau, thought that the notion of restrained war was inspired by the postulates of the founding fathers. Realists even consider it to have been a key concept in the US foreign policy from the foundation of the Republic (Morgenthau, 1976).

Moreover, the national interest was interpreted as the physical, cultural and political survival of the nation (Morghentau, 1952b). However, they excessively justified the use of the force and gave moral support to certain cynicism by military forces. The limit between the use of armed force and the use of every kind of pressure methods was blatantly exceeded once and again, because in politics of power everything became legal (Riera, 2010). After all, as pointed out by Burnham, the principles of political struggle are identical to those of military struggle: success depends on knowing how to get hold of the situation. For his part, Aron, maybe less harsh but equally incisive, stated that "the military leader is accountable to his nation for his actions, his successes or his defeats. What do good intentions and respect for private virtues matter? The law of diplomacy or strategy is a different thing" (Aron, 2003).

One of the most insightful critics to realism as it was understood by theorists of the National Security Doctrine came precisely from Raymond Aron, who himself was a Realist and the theoretical expression of Gaullism in France. Aron believed that realism, obsessed as it was with refuting the liberalism ideal that every man could be disciplined by making him follow laws and moral precepts, opposed one Anthropology to another, and power to law or morality.

"The American realists, we have said, are located on the margin of the idealist situation and come later in time. They think against, they criticize the picture the idealists present of the world or the precepts they formulate. They are led, without being fully aware of it, to follow the example of those whom they oppose" (Aron, 2003).

In fact, Aron stated that Morgenthau did more praxeology than theory and that he was "a crusader, but a crusader of realism" (Aron, 2003). However, he acknowledged it was necessary a certain amount of realism in order to get away from the inconsistencies of an excess of good will. Realism was "a necessary reaction against the naïve conception of an international order which would stand of its own accord, without any other basis than respect for the law, against the false idea that it suffices to apply principles (...) in order to settle conflicts peacefully. Unfortunately, by mixing theory and praxeology, and by lacking a rigorous distinction between the permanent characteristics and the historical particulars of international politics, the realist school has arrived at an ideology comparable to that which it took for the target of its criticisms." (Aron, 2003)

That is why Aron considered that true realism consisted in acknowledging the effect of ideology over diplomatic and strategic behaviours. In order to understand the diplomacy and the strategy of a State it is necessary to know its regime and the philosophy of its leaders.

"A true realism takes into account the whole of reality, dictates diplomatic-strategic conduct adapted not to the finished portrait of what international politics would be if statesmen were wise in their selfishness, but to the nature of the passions, the follies, the ideas and the violence of the century" (Aron, 2003).

\section{Conclusions}

The aforementioned ideas help to better understand the true sense of realism and its contradictions, and tangentially the inconsistencies of the National Security Doctrine. It is not strange that those who promoted the National Security Doctrine liked realism especially Kennan and Niebuhr, even though they misinterpret them so much. It was not for nothing that the times the promoters of the National Security Doctrine were living in the "laboratory" of the realists were the harsh 1960s, 1970s and 1980s. The emergence of neorealism reinforced their theses and their application in the Latin American authoritarian regimes of that period. Such ideological trend developed by the end of the 1970s because transnational postulates were not enough to coherently explain international affairs and because the international context of that time boosted a return to Realism. Following the success of the Iranian revolution, the Soviet invasion of Afghanistan and the installation of SS-20 missiles in Europe there was a return to a certain degree of containment, because the situation was similar to that of the 1940 s and the 1950s.

As a result of that, devotees of the National Security Doctrine could constantly invoke those postulates once their projects had started. And that is also why they justified the excessive use of the force and gave moral support to the cynicism of the military power that was characteristic of the National Security regimes. It was true that Niebuhr had insisted that the nations were more united by the use of the force and by emotional bonds than by the reason, but he never divest Realism of rationality and sensibility, unlike the creators of the National Security Doctrine, who support their views with a mistaken Schmittian interpretation. 
It is true that Morgenthau said that the first thing that configured the national interest was the survival of the nation and therefore the States used whatever methods they could to achieve that goal. But it was the trust in democracy and the will to support it what inspired these ideas. In other words, the fear to unrestrained despotism and the will to fight it inspired political realism and made it essentially different to the National Security Doctrine. The latter made the national interest become one of its key arguments, but at the same time it never understood what the national interest actually was. It is true that Kissinger proposed to hold back revolutionary powers in order to keep the international system stable, and that this led him to support morally dubious actions, such as the spread of the war in Vietnam to Laos and Cambodia. However, he did that in the sake of balance, not aiming to eradicate the enemy.

Osgood insisted that wars declared to achieve transcendent goals were immoral because they did not delimited reality. Nonetheless supporters of the National Security Doctrine invoked the defence of moral values and the highest ideals such as the cause of "war", which used to be applied against civil people. It is true that political realism was never quite scrupulous when it came to cross the line between the use of armed forces and other ways of exerting pressure, but it never considered it legitimate to use all methods at the government's disposal to fight internal enemies. Besides, realism considered it crucial to install a system of balance of power, at least as a theoretical reference; while the National Security Doctrine was born in times of bipolarity, where it was impossible to find pure balance. That was why the latter joined with pleasure the Cold War world, so it could not be considered a direct heir of political realism.

Thus relevant differences between classical political realism and the National Security Doctrine have been observed. After all, as the study or mere observation of History suggests, the National Security States were born after the armed forces signed an alliance with the internationalised high bourgeoisie. They did control popular participation in public affairs too, and tried to promote indifference amongst the masses towards their behaviour. They abolished political parties, formed technocratic governments; they had a very deeply-rooted hierarchical mentality, and limited political and human rights through the use of violence. All of that has almost nothing to do either with the complexity of the realist theory, nor with the will of realist authors to keep stability, and to assure the survival of democracies.

\section{References}

Aron, R. (2003). Peace and War: A Theory of International Relations. New Brunswick, NJ: Transaction Publishers.

Burnham, J. (1947). The Struggle for the World. New York: The John Day Company Inc.

Davis, H, \& Good, R. (1960). Reinhold Niebuhr on politics. His Political Philosophy and its Application to Our Age as Expressed in his Writings. New York: Scribner.

Emerson, E. W., \& FORBES, W. E. (Eds.). (1910-14). Journals of Ralph Waldo Emerson. Boston and New York: Houghton Mifflin.

Fallaci, O. (1976). Interview with History. New York: Liveright.

Gaddis, J. L. (1982). Strategies of Containment. New York: Oxford University Press.

Hall, J. A., \& Ikenberry, J. G. (1989). The State. Milton Keynes: Open University Press.

James, H. (1920). Letters. New York: Charles Scribner's Sons.

Kant, I. (2005). Perpetual Peace. New York: Cosimo In.

Kennan, G. (1947). The Sources of Soviet Conduct. Foreign Affairs, 25 (4), 566-582. http://dx.doi.org/10.2307/20030065

Kennan, G. (1954). Realities of American Foreign Policy. Princeton: Princeton University Press.

Kissinger, H. (1973). A World Restored: Metternich, Castlereagh and the Problems of Peace (pp. 1812-1822). New York: Mariner Books.

Kissinger, H. (1995). Diplomacy. New York: Touchstone.

Lenin, V. I. (1919). Report of the Central Committee. Eighth Congress of the R.C.P. (B.), March 18-23.

Marx, K., \& Engels, F. (1998). The Communist Manifesto, New York: New American Library (Penguin Group).

Mcilwain, C. H. (2005). Constitutionalism: Ancient and Modern. New Jersey: The Lawbook Exchange.

Morgenthau, H. (1952a). American Foreign Policy. A Critical Examination. London: Methuen \& Co. Ltd. 
Morgenthau, H. (1952b). Another Great Debate: The National Interest of the United States. The American Political Science Review, 46 (4), 961-968. http://dx.doi.org/10.2307/1952108

Morgenthau, H. (1976). Founding Fathers and Foreign Policy: Implications for the Late Twentieth Century. Orbis, 20 (1), 15-25.

Morgenthau, H. (1977). Politics Among Nations. The Struggle for Power and Peace. New York: Alfred A. Knopf.

Morgenthau, H. (2004). Political theory and international affairs: Hans J. Morgenthau on Aristotle's The Politics. Westport: Praeger Publishers.

Niebuhr, R. (1944). The Children of Light and the Children of Darkness. New York: Charles Scribner's Sons.

Niebuhr, R. (2002). Moral man and immoral society: A study in ethics and politic. Louisville (Kentucky): Westminster John Knox Press.

Niebuhr, R. (2008). The Irony of American History. Chicago: University of Chicago Press.

Osgood, R. (1957). Limited War. Chicago: University of Chicago Press.

Osgood, R. (1977). The Mission of Morgenthau. In Thompson, Kenneth, \& Myers, Robert (Eds.), Truth and Tragedy: A Tribute to Hans Morgenthau. London: New Brunswick.

Riera, E. (2010, summer). Interview carried out in Buenos Aires with a high-rank officer of the Argentine Army and University rofessor.

Rosenau, J. (1972). National Interest. In Sills, D. (Ed.), International Encyclopedia of the Social Sciences. New York: McMillan Company \& The Free Press.

Schlesinger, A. (1999). The Cycles of American History. New York: Mariner Books.

Schlesinger, A. (2004). The Imperial Presidency. New York: Mariner Books.

Stalin, J. V. (2001). Concerning Questions of Leninism. In Stalin, Joseph V. (Ed.), Problems of Leninism. Peking: Foreign Languages Press.

Thompson, K. (1960). Political realism and the crisis of world politics. Princeton: Princeton University Press.

\section{Notes}

Note 1. Spykman influenced, at the same time, in Foster Dulles, Kennan and Kissinger. His thinking contributed to build the theory of containment politics and, despite he wrote only two books, they were exceptional, America's Strategy in World Politics, the United States and the Balance of Power, and The Geography of the Peace, published a year after his decease. Though he died in 1943 at only 49 years of age, he was able to change the views on how international order should be.

Note 2. One of the most interesting critics to the realist school is to be found in Aron (2003: 665-702).

Note 3. The latter is a political axiom. See, for example, Osgood (1977: 33).

Note 4. In other words, it is possible that a State that wants to defend high moral principles could bring war to the destruction of an enemy State considered to be responsible for the evils of a society -for example, having caused the war itself-. And, in doing so, the former may be more immoral than other that only defends its own interests and, precisely because of that, limits its violence when fighting against other State. If a State considers itself to be a body that is morally superior to others and believes to be defending the highest principles -that is, pure justice-, it may become more dangerous than other State that was more "mediocre", morally speaking.

Note 5. In fact, on February 22nd 1946 he sent a eight thousand words text from Moscow, where he worked as the head of the business office. The paper was called "The origins of Soviet behaviour" and was later published in Foreign Affairs in July 1947, under the pseudonym of Mister X. The paper is available at http://www.historyguide.org/Europe/kennan.html (last search: Dec-9).

Note 6. See also Thompson (1960: 60-61).

Note 7. That was the World situation from 1812 to 1822 . There are few moments in History that exemplified so clearly how the emergence of a revolutionary power could question the international order. The balance of power based on the consensus of the big powers brought stability back to Europe. That is the main thesis of $A$ World Restored: Metternich, Castlereagh and the Problems of Peace, 1812-1822, where Kissinger (1973) summarised most of his postulates, which he tried to apply to the times in which he worked as a politician.

Note 8. In fact, this Neorealism or structural realism is an evolution of classical Realism and prefers to analyse 
the structure of the international system in order to understand the complex world of international relations. The most relevant authors are, probably, Waltz, Gilpin, and Keohane, although Krasner, Grieco, Art, Jervis, Schweller or Mearsheimer are also worth a mention. Nevertheless, we believe their relevance cannot be compared to that of classical Realist authors. That does not deny that, since the $1980 \mathrm{~s}$, the main debates within the field of international relations have been led by both neorealists and neoliberals, as the former are still worried about the anarchy of the international order, the weakness of international institutions which make true international cooperation more difficult, or the capacities of the States, while the latter are more interested in the will of the institutions which allows in itself solid cooperation, the economy or the environment, which lessen the anarchy. 